\title{
L'art de faire des pantalons et la quatrième dimension...
}

\section{Françoise Cousin}

\section{(2) OpenEdition}

1 Journals

Édition électronique

URL : https://journals.openedition.org/tc/651

DOI : $10.4000 /$ tc. 651

ISSN : 1952-420X

Éditeur

Éditions de l'EHESS

\section{Édition imprimée}

Date de publication : 1 novembre 1993

ISSN : 0248-6016

\section{Référence électronique}

Françoise Cousin, "L'art de faire des pantalons et la quatrième dimension... », Techniques \& Culture [En ligne], 20 | 1993, mis en ligne le 05 janvier 2006, consulté le 29 septembre 2022. URL : http://

journals.openedition.org/tc/651; DOI : https://doi.org/10.4000/tc.651

Ce document a été généré automatiquement le 29 septembre 2022.

Tous droits réservés 


\section{L'art de faire des pantalons et la quatrième dimension...}

Françoise Cousin 